\title{
The pharmacology and activity of non-steroidal anti-inflammatory drugs (NSAIDs): a review of their use as an adjuvant treatment in patients with HBV and HCV chronic hepatitis
}

Farmacologia e attivitá dei farmaci anti-infiammatori non steroidei (NSAIDs): una revisione della indicazione al loro uso come trattamento adiuvante dei pazienti con epatite cronica HBV e HCV correlata

\section{Sirio Fiorino ${ }^{a, *}$, Carmela Cursaro ${ }^{b}$, Stefania Lorenzini ${ }^{b}$, Elisabetta Loggi ${ }^{b}$, Lucia Brodosi $^{\mathrm{b}}$, Laura Cattani ${ }^{\mathrm{a}}$, Andrea Cuppini ${ }^{\mathrm{a}}$, Mauro Bernardi ${ }^{\mathrm{b}}$, Pietro Andreone ${ }^{b}$}

\footnotetext{
a Dipartimento di Medicina Interna, Azienda Unità Sanitaria Locale, Ospedale di Budrio, Bologna, Italy

${ }^{\mathrm{b}}$ Dipartimento di Medicina Clinica Università di Bologna, Italy
}

Received 26 November 2010; accepted 21 February 2011

available online 8 April 2011

\section{KEYWORDS}

Prostaglandin E2; Hepatitis B Virus; Hepatitis C Virus; Chronic hepatitis; Non-steroidal antiinflammatory drugs (NSAIDs).

\begin{abstract}
Summary
Introduction: Different DNA and RNA viruses exploit common strategies to support their persistence and replication in infected individuals. In particular, the hepatitis B virus (HBV) and the hepatitis $C$ virus (HCV) cause major health problems worldwide. These pathogens exert an immunosuppressive role by inducing the persistent activation of cyclooxygenase-2 (COX-2) and an increased synthesis of prostaglandin E2 (PGE2). The suppression of this proinflammatory network by non-steroidal anti-inflammatory drugs (NSAIDs) has been proposed as a therapeutic approach to decrease viral replication.

Materials and methods: In this review, the role of inflammation in the support of viral replication and NSAIDs and ketoprofen pharmacology are briefly discussed. In addition, studies that have investigated the use of NSAIDs for the treatment of HBV and HCV chronic hepatitis, which were identified by a systematic literature search of PubMed and MEDLINE, are reported.
\end{abstract}

\footnotetext{
* Corresponding author: UO di Medicina Interna, Ospedale Budrio, via Benni 44 - 40065 Budrio (BO), Italia.

E-mail: sirio.fiorino@ausl.bologna.it (S. Fiorino).
} 
Results: To date, pegylated-interferon (PEG-IFN) and/or nucleot(s)ide analogues and PEG-IFN and ribavirin remain the standard therapy for HBV and HCV chronic hepatitis, respectively. Discussion: The use of NSAIDs in patients with chronic viral hepatitis has only a "historical" interest. Nevertheless, the possible usefulness of ketoprofen with PEG-IFN and ribavirin for HCVinfected patients, non-responders to standard therapy or with genotype 1 , should be evaluated in future clinical studies.

(c) 2011 Elsevier Srl. All rights reserved.

\section{Introduction}

Hepatitis B (HBV) [1] and C viruses (HCV) [2] are common infectious agents worldwide and represent serious public health problems. These viruses may cause chronic infections and induce necroinflammatory hepatic damage with potentially severe sequelae, such as cirrhosis, hepatocellular carcinoma and liver failure [3-7].

Interferon-Alpha (IFN- $\alpha$ ) alone is the treatment of choice for HBV and HCV chronic hepatitis, but the virological response rates are unsatisfactory $[8,9]$. Therefore, new strategies for the treatment of chronic viral hepatitis have been developed. The current gold-standard therapies rely upon nucleot(s)ide analogues or PEG-IFN for chronic HBV infection, and pegylated-interferon (PEG-IFN) in association with ribavirin for HCV infection [10,11]. Nevertheless, these regimens do not achieve a sustained response in all patients. Therefore, the introduction of new, tolerable and efficacious therapies is mandatory. Recently, novel potential anti-HCV drugs, such as the anti-viral therapy specifically targeted for hepatitis C (STAT-C), are under clinical phase I-III evaluation. These therapies might improve antiviral activity in subjects with HCV genotypes 1 and 4 in particular, who are characterized by a lower response rate compared to genotypes 2 and 3 $[12,13]$. Unfortunately, preliminary data report the development of drug resistance mutations, which is similar to the results obtained with anti-HIV and anti-HBV treatments [14].

Some in vitro and in vivo studies have shown that the antiviral efficacy of IFN- $\alpha$ treatment, in both HBV and HCV patients, may be enhanced by the addition of NSAIDs [15-21].

The aim of this review is to examine the following data:

1) the role of inflammation in viral replication support;

2) the function of the interferon system;

3) the prostaglandin synthesis pathway;

4) prostaglandin E2 as an immune system modulator;

5) the pharmacology of NSAIDs and ketoprofen;

6) the role of NSAIDs in the treatment of patients with HBV and HCV chronic viral hepatitis.

\section{Role of inflammation in viral replication support}

Viral infection generates a strong acute host reaction and activates many preexisting antiviral defense systems in infected cells [22]. Early host responses to viral infection are generally nonspecific and include the induction of an inflammatory reaction with the production and release of several soluble factors, such as interferons (IFN) [23], prostaglandins and cytokines, by distinct cellular effectors of the immune system [24]. Subsequently, a virus-specific immune response develops with the emergence of specific CD4 and CD8 T lymphocytes [25]. A complex relationship exists among the members of specific and nonspecific immune responses [26]. The final result of these events is the control of viral replication and the prevention of viral spreading [27]. Although these mechanisms develop to ensure an effective host defense against intracellular invading pathogens and play a crucial protective role [28], their activation may have deleterious effects for infected organisms [29]. In the last several years, it has become increasingly clear that several viruses may benefit from the induction of a strong inflammatory response [30]. Several viruses in humans and animals, such as herpesviruses (HSV) [31], cytomegalovirus (HCMV) [32], Epstein-Barr virus [33], human immunodeficiency virus (HIV) [34], and hepatitis B and C viruses [35,36], exploit common and effective strategies to support their persistence and replication in infected individuals through the modulation and perturbation of host defenses [37]. Several virus-specific proteins that are produced during the viral life cycle affect intracellular pathways and immune effector cells by stimulating specific molecules and proinflammatory cytokines that prevent an effective antiviral response $[38,39]$. In particular, prostaglandin E2 (PGE2) has a pivotal role in the inflammatory reaction [40] and serves as a second messenger by eliciting a wide spectrum of cellular physiological functions [41]. Different viruses stimulate the synthesis of PGE2, which, in turn, supports the production of its progeny. The complex interplay of signals and the factors that are involved in this control-regulatory loop during the course of HBV and HCV chronic infections are discussed briefly below.

\section{Interferon system function}

Following a viral infection, an early inflammatory response in mammals is represented by the induction and release of IFNs, including interferon- $\alpha$ (IFN- $\alpha$ ), $-\beta$ (IFN- $\beta$ ) and $-\gamma$ (IFN- $\gamma$ ) [42]. These regulatory proteins act by promoting a global antiviral state and inhibiting viral replication. Hematopoietic cells in particular, plasmacytoid dendritic cells, are the cellular source of IFN- $\alpha$ [43]; non-hematopoietic cells, such as fibroblasts, produce IFN- $\beta$ [44]. The binding of IFN- $\alpha$ to its receptor activates different enzymes, including the receptorassociated Janus-family kinases, Tyk- 2 and Jak- 1 , and signal transducers and activators of transcription proteins (STAT) [45]. Different mechanisms control this complex pathway [46]. In addition, IFN- $\alpha$ induces the phosphorylation of phospholipase A2 (cPLA-2), an enzyme that catalyzes phospholipid hydrolysis and arachidonic acid (AA) release from the 
cellular membrane [47]. AA is a substrate for cyclo-oxygenase-, lipoxygenase- and epoxygenase-enzymatic pathways for the synthesis of prostaglandins (PGs), leukotrienes and other eicosanoids [48]. AA also stimulates mitogen-activated protein kinases (MAPKs), which promote the activation of STAT1 via phosphorylation at serine residues $[49,50]$.

\section{Prostaglandin synthesis pathway}

The synthesis of PGs is mediated by COXs. These COX enzymes, also named prostaglandin $\mathrm{H}_{2}\left(\mathrm{PGH}_{2}\right)$ synthases, have both a COX activity, which catalyzes the conversion of AA to prostaglandin $G_{2}\left(P G G_{2}\right)$, and a peroxidase function, which induces the reduction of $\mathrm{PGG}_{2}$ to $\mathrm{PGH}_{2}$ [51]. Two distinct isoforms of COX have been well characterized. COX-1 is constitutively present in different cell types, but COX-2 expression is induced by cytokines and growth factors [52]. COX-2 induction is promoted [53] by the oxidative stress that is caused by viral infections [54,55]. $\mathrm{PGH}_{2}$ is a common precursor for the synthesis of all prostanoids, including $\mathrm{PGE}_{2}$ [56]. A variety of DNA and RNA viruses, including HSV, HCMV, HIV, HBV and HCV, up-regulate COX-2 activity [57-61]. COX-2 expression and PGE2 synthesis are essential events for an efficient viral replication in infected hosts, modulating transcription from viral promoters. The inhibition of COX-2 activity by drugs reduces viral progeny in cultured cells [32], but supplementation with PGE2 has the opposite effect. Nevertheless, the PGE2 that is generated by COX-2 activation down-regulates HBV and HCV replication $[57,58]$. The discrepancy between these results might be related to the types of cells and the conditions of culture.

\section{Prostaglandin E2 as a modulator of the immune system}

It has become increasingly clear that PGE2 plays a critical immunosuppressive role [62]. PGE2 modulates host defenses against invading pathogens by affecting both the innate and adaptive arms of the immune system [63]. Namely, PGE2 inhibits nitric oxide (NO) production and down-regulates the CD4+ $\mathrm{T}$ helper 1 (Th1) lymphocyte response [64], which decreases interleukin-2 (IL-2), IL-12 and IFN- $\gamma$ production [65]. NO is a cytotoxic compound with antimicrobial and antiviral properties. In particular, NO reduces the replication of both DNA and RNA viruses. PGE2 counteracts the antiviral effects of NO through a negative feedback loop [66] and interferes with the production of cytokines. The immunosuppressive effects of PGE2 synthesis have also been described in patients with chronic liver disease. The inhibition of COX enhances IFN- $\gamma$ release by peripheral blood mononuclear cells [67], and treatment with intravenous and oral PGE2 in patients with either fulminant viral hepatic failure or recurrent $\mathrm{HBV}$ infection after orthotopic liver transplantation has resulted in a dramatic improvement in their survival [68]. The inhibition of PGE2 production may enhance the Th1 response and improve the antiviral function of the immune system. Among the different compounds with these activities, NSAIDs possess very interesting properties. In fact, NSAIDs control cytokine production by $\mathrm{T}$ lymphocytes [69] through an up-regulation of tumor necrosis factor $\alpha$ (TNF- $\alpha)$,
IL-2 and IFN- $\gamma$ and the inhibition of the release of IL- 4 and IL6. In 2004, a study tested the in vitro effect of indomethacin and IFN- $\alpha$ on Th1 and Th2 cytokine synthesis in patients with chronic hepatitis $C$ [17]. The results demonstrated that IFN-a and indomethacin alone were able to increase Th1 response, while their association caused a further synergistic effect, counteracting the synthesis of Th2 cytokines and increasing both the IFN-a-induced Th1 response and antiviral protein 2, 5 (OAS).

\section{Pharmacology of ketoprofen}

\section{Absorption, distribution and metabolism}

Among the NSAIDs, ketoprofen is a paradigm and displays anti-inflammatory, analgesic and antipyretic properties by the inhibition of prostaglandin and leukotriene synthesis [70]. Its structural formula is depicted in Figure 1.

Ketoprofen is a racemic compound with only the $S(+)$ enantiomer exhibiting pharmacological properties [71]. After administration, the drug is rapidly absorbed in the stomach and bound to plasma proteins, such as albumin. The total bioavailability of ketoprofen is not modified by meals, and its absorption is not changed by antiacids. Ketoprofen is mainly metabolized via glucuronide conjugation to generate an unstable acyl-glucuronide, which may be reverted to the parent form. Therefore, a progressive accumulation of glucuro-conjugated drug with the possible regeneration of active molecules may occur.

No important differences in efficacy and safety have been detected in several previous studies that have compared ketoprofen, aspirin, ibuprofen, naproxen, piroxicam, diclofenac and indomethacin [72].

\section{Role of non-steroidal anti-inflammatory drug (NSAIDs) in the treatment of patients with chronic viral hepatitis}

Patients with HBV and HCV chronic hepatitis have a persistent activation of COX-2 and a subsequently increased PGE2 production compared to control subjects $[53,57,58]$, even after an efficacious antiviral therapy. The expression of COX2 and the synthesis of PGE2 lead to reactive oxygen species (ROS) generation. This process is caused by virus-induced cellular oxidative stress via calcium release from the endoplasmic reticulum and its uptake by mitochondria $[53,58]$. ROS act as second messengers and activate NF-kB $[36,53]$.

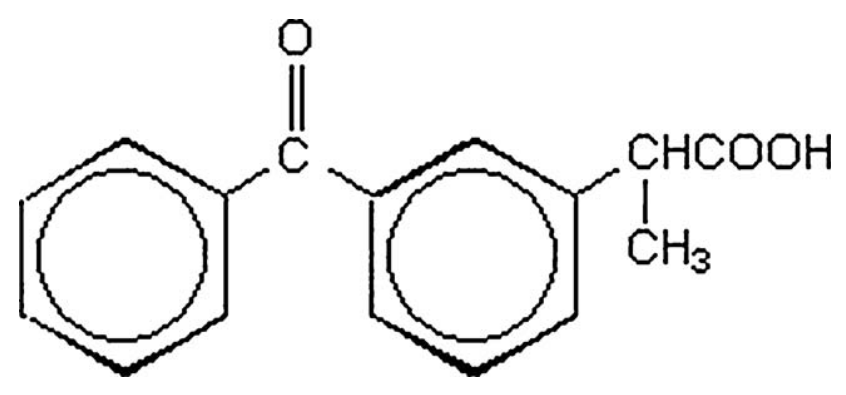

Figure 1 Chemical structure of ketoprofen. 
NF-kB binding sites have been detected in the COX-2 promoter/enhancer region; therefore, NF-kB controls COX-2 gene expression [73]. The NSAID-induced inhibition of PGE2 production is expected to decrease viral replication [37,32]. Clinical studies in patients with HBV and HCV chronic hepatitis also suggest that NSAIDs cause both the enhancement of IFN- $\alpha$-induced 2,5-OAS, which is an enzyme that exhibits strong antiviral properties, and the increase of IFN- $\alpha$-dependent gene activation. In 1991, Hanningan and Williams, in an in vitro study, reported that the in vitro NSAID inhibition of COX and lipoxygenase activities promotes a marked amplification of the IFN signal, which shifts AA toward the epoxygenase enzymatic metabolic pathway with the consequent induction of 2,5-OAS [48]. Fibroblasts cultured either with IFN- $\alpha$ plus indomethacin or indomethacin alone demonstrate a 3- or 0.5-fold enhancement of 2,5 OAS, respectively, compared to fibroblasts treated with IFN- $\alpha$ alone [74]. In 1993, Andreone et al. reported that indomethacin abolished the IFN- $\alpha$-induced enhancement of PGE2 synthesis in cultured liver tissue from patients with HBV and HCV chronic infections [21]. In 1994 and 1996, two further in vitro and in vivo studies confirmed that IFN- $\alpha$ and indomethacin exert a synergistic activity and induce a 4-fold increase in 2,5-OAS production in subjects with HBV and HCV chronic hepatitis $[20,75]$. An in vitro study has suggested that indomethacin, via blockade of AA metabolism, promotes IFN- $\alpha$-dependent transcription via an increase of STAT1 tyrosine phosphorylation [16]. In addition, acetylsalicylic acid inhibited HCV RNA and protein expression in a hepatoma cell line, which contained an HCV subgenomic replicon, via its suppressive activity on COX-2 expression. This effect was mediated in part by the activation of the MAPK/extracellular signal-regulated kinase kinase [76]. These interesting results provided the rationale to test the efficacy, tolerability and safety of IFN- $\alpha$ plus NSAIDs in clinical trials in patients with HBV- and HCVrelated chronic liver disease. Different NSAIDs with distinct pharmacologic properties have been used, including indomethacin, ketoprofen and tenoxicam, with conflicting results.

\section{Trials evaluating NSAIDs alone or in association with IFN- $\alpha$ as a treatment for patients with HBV chronic hepatitis}

To date, only a few studies have tested the association between IFN- $\alpha$ and NSAIDs as a treatment for patients with HBV chronic liver disease. A pilot trial reported that the administration of IFN-a (6 MU thrice weekly) plus indomethacin ( $25 \mathrm{mg}$ orally twice a day) for six months induced a biochemical ( 3 out of 6 cases) and virological (1 case) response in patients with $\mathrm{HBeAg}$ positive chronic hepatitis, non-responders to a previous IFN-a course. Interestingly, further transaminase normalization (1 patient), HBV DNA loss ( 2 patients), and $\mathrm{HBeAb}$ seroconversion ( 1 patient) occurred during the 6-month period of observation that followed treatment. This therapy was well tolerated, and no important side effects were reported [75]. Two further randomized studies have been performed to examine the effects of indomethacin alone in patients with HBV chronic infection with an asymptomatic course. In the first study, chronic HBV "inactive" carriers were randomized into two groups: 1) 42 patients were treated with oral indomethacin
$75 \mathrm{mg}$ a day for 6 months, and 2) 23 patients served as controls. All patients were followed-up for 6 months after treatment. Indomethacin induced $\mathrm{HBeAg}$ to $\mathrm{HBeAb}$ seroconversion and HBV-DNA loss in a significantly higher number of patients in comparison to controls [77]. In 2005, the results of a larger placebo-controlled double-masked study, which enrolled 112 asymptomatic persistently infected HBV subjects randomized into two groups, were published. The first group, which included 56 patients, was treated with indomethacin $25 \mathrm{mg}$ three times a day, and the second group received a placebo. All patients received treatment for 6 months and were followed up for a further 3 months. The primary end-point was HBeAg to $\mathrm{HBeAb}$ seroconversion, and HBV DNA clearance and HBsAg loss were secondary end-points. At the end of study, HBsAg loss was observed in two patients in each group, and HBV DNA was undetectable in 7 patients that received indomethacin compared to 1 patient in the placebo group. HBeAb seroconversion only occurred in 5 subjects in the indomethacin group. Hepatotoxicity (one patient) and gastritis (two patients) were the reported side effects in the indomethacin group versus one case of suspected drug-induced gastritis in the placebo group [16].

\section{Trials evaluating the association of NSAIDs with IFN- $\alpha$ as a treatment for patients with HCV chronic hepatitis}

The use of NSAIDs plus IFN- $\alpha$ for the treatment of patients with HCV chronic hepatitis has produced conflicting results. In 1997, Anderson et al. treated 17 patients with HCV chronic infection non-responders with a six-month course of therapy with IFN- $\alpha-2 b 3 \mathrm{MU}$ trice a week and the administration of IFN- $\alpha-2 b 3 \mathrm{MU}$ plus ketoprofen for a further four months. No improvement in the response rate was obtained because no significant differences in mean serum aminotransferases were detected after the addition of NSAIDs. Serum HCV RNA only became transiently negative in one patient. This study has two potential pitfalls: 1) the absence of a control group, and 2) the inclusion of patients with cirrhosis, who present a poor response rate to interferon [78]. A subsequent randomized double-blinded study enrolled 149 naive patients with HCV active chronic hepatitis. Seventy-six subjects received IFN- $\alpha$-2a 3 MU trice a week plus placebo, and 73 patients were treated with IFN- $\alpha-2$ a 3 MU trice a week plus tenoxicam $(20 \mathrm{mg} /$ day $)$. The treatments lasted 6 months and were followed by a 6-month follow-up period. The combination of IFN- $\alpha$ and tenoxicam was well tolerated, but no differences in biochemical and virological responses, as measured by the lack of a peak in 2,5-OAS activity, were detected in both groups at the end of either the treatment period or the follow-up [79]. A significant peak in 2,5-OAS activity was obtained only in patients treated with IFN- $\alpha$ at month 3 . In 1999, Fabris et al. performed a trial in 50 patients with HCV chronic hepatitis that were randomized to receive IFN- $\alpha-2 b$ from 3 to $8 \mathrm{MU}$ trice a week for 6 months alone (24 subjects) or in combination with ketoprofen $200 \mathrm{mg} /$ day for 5 days a week (26 subjects). The post-treatment follow-up period lasted 12 months. No differences in complete response, which was defined as serum HCV RNA undetectability, and sustained response, which was defined as negative HCV RNA in serum following 6 and 12 months after treatment, were 
observed. The incidence of side effects was not significantly different between the two groups [80].

However, a few trials have suggested that NSAIDs enhance the antiviral effects of IFN- $\alpha$. In 1999, Andreone et al. evaluated the efficacy and tolerability of ketoprofen in 59 with chronic HCV-related hepatitis non-responders to a fivemonth course of IFN therapy. These patients were randomly assigned to three treatment regimens for four months without withdrawing IFN: 1) 16 patients received leukocytic IFN- $\alpha 6$ MU alone trice a week, 2) 17 patients received IFN- $\alpha 6$ MU trice a week plus ketoprofen 150 mg twice daily, and 3) 16 patients received IFN- $\alpha 6 \mathrm{MU}$ trice a week plus ribavirin $400 \mathrm{mg}$ twice daily. Ten patients were excluded because of contraindications to the combined therapy (e.g., peptic ulcers or anemia). The post-treatment follow-up period lasted 6 months. Despite the short duration of the combination therapy, the addition of ketoprofen to IFN induced an end-treatment complete response (i.e., normal transaminases and undetectable HCV RNA) in 4/16 patients, which is a response rate that is similar to treatment with IFN- $\alpha$ plus ribavirin (4/14 patients). Only 1 patient achieved this in group A. At the end of the follow-up period, the complete response was maintained in $0 / 15,3 / 16$ and $2 / 14$ subjects, respectively, and histological improvements were observed in patients with a complete response [19]. Mild side effects were described in the group of patients treated with ketoprofen. A further trial confirmed that the virological response was improved by the administration of IFN- $\alpha 2 b$ combined with ketoprofen at different doses in naïve patients with HCV chronic hepatitis, about $1 / 3$ of whom had compensated cirrhosis. Seventy patients were randomized to three groups: 23 subjects received IFN- $\alpha 2$ b 3 MU trice weekly (group 1), 23 patients received IFN- $\alpha 2 b 3 \mathrm{MU}$ trice weekly plus ketoprofen $200 \mathrm{mg}$ trice a week (group 2), and 24 patients received IFN- $\alpha$ 2b $3 \mathrm{MU}$ trice weekly plus ketoprofen $200 \mathrm{mg}$ twice a day (group 3). Patients received therapy for 6 months and were followed-up for another 6 months. The combination of IFN- $\alpha$ $2 \mathrm{~b}$ with daily ketoprofen administration significantly improved the response to treatment, which was measured as a complete response (i.e., end-treatment normal serum transaminases and negative serum HCV RNA), was observed in $10 \%$ (group 1), 5\% (group 2) and 29\% (group 3) of patients. A sustained response (i.e., normal serum transaminases and negative serum HCV RNA at the end of follow-up) was observed in $5 \%, 0 \%$ and $26 \%$ of subjects in groups 1,2 and 3 , respectively. The IFN- $\alpha 2 \mathrm{~b}$ - ketoprofen combination was well-tolerated and reduced the incidence of flu-like syndrome. All of the groups presented a similar incidence of gastric symptoms, but anemia prevailed in patients receiving ketoprofen [81].

In 2003, Andreone et al. conducted a study to evaluate the efficacy and safety of the combination of IFN- $\alpha$ and ketoprofen in naïve HCV patients with chronic hepatitis $C$. Overall, 40 patients received IFN- $\alpha 2$ a $3 \mathrm{MU}$ trice a week and 40 patients received IFN- $\alpha 2$ a 3 MU trice a week plus ketoprofen $150 \mathrm{mg}$ twice daily. Treatments lasted 6 months, and patients were followed-up for 6 months. At the end of treatment, 7/40 patients in the IFN- $\alpha$ group and 14/40 in the IFN- $\alpha$ plus ketoprofen group achieved a virological response (i.e., undetectable HCV RNA), which was maintained at the end of the observation period in 4/40 and 13/40 patients, respectively. Asthenia and flu-like syndrome were significantly more common with IFN- $\alpha$ alone, but epigastric pain and anemia were more frequent with the combination therapy [18]. In 2009, Andreone et al. performed a pilot phase II study to assess the effect of ketoprofen plus PEG-IFN $2 a$ (PEG-IFN- $\alpha 2 a$ ) with or without ribavirin in comparison to PEG-IFN- $\alpha$ 2a plus ribavirin on viral kinetics, STAT1 activity, the expression of the IFN-dependent gene, 2,5-OAS, and safety and tolerability in 45 treatment-naïve subjects with genotype 1 chronic HCV hepatitis. Patients were randomized to receive the following drug combinations: 15 patients received PEG-IFN- $\alpha$ 2a $180 \mu \mathrm{g} / \mathrm{wk}$ plus oral ribavirin $800 \mathrm{mg} /$ day for 48 weeks (PR group); 16 patients received PEG-IFN- $\alpha$ 2a $180 \mu \mathrm{g} /$ wk for 48 weeks plus oral ketoprofen $200 \mathrm{mg}$ twice daily for the first 4 weeks and $200 \mathrm{mg} /$ day for the next 20 weeks (PK group); 14 patients received PEG-IFN$\alpha 2 \mathrm{a} 180 \mu \mathrm{g} / \mathrm{wk}$ plus oral ribavirin $800 \mathrm{mg} /$ day for 48 weeks plus oral ketoprofen $200 \mathrm{mg}$ twice daily for the first 4 weeks and $200 \mathrm{mg} /$ day for the next 20 weeks (PRK group). The addition of ketoprofen to standard therapy caused an early and sustained activation of 2,5-OAS transcription and an early but less sustained activation of STAT1. Although subjects in the PR group had a lower viral load compared to the PK and PRK groups, a better sustained virological response and a lower relapse rate were observed in PRK patients. Ketoprofen use was well tolerated and safe, and only slight gastrointestinal adverse events were reported. In addition, neither a dose decrease nor treatment discontinuation was necessary [82].

\section{Conclusion}

Conflicting data have emerged from trials that enrolled patients with either HBV or HCV chronic hepatitis, who were either naïve or non-responders to a previous therapy course. Nevertheless, the combination of IFN- $\alpha$ and ketoprofen has provided encouraging results. The discrepancy between the data obtained in these clinical trials may be related to distinct factors, such as the different COX and lipoxygenase inhibitory activities of NSAIDs, the dose used, the trial design and duration and the number of participants. The combinations of PEG-IFN and ribavirin in HCV chronic hepatitis and PEG-IFN and/or nucleot(s)ide analogues in HBV chronic hepatitis are more effective than the association of IFN- $\alpha$ plus ketoprofen and are actually seen as the best therapies. Moreover, these treatment regimens and the newly proposed drugs, such as STAT-C, significantly improved the antiviral response rate and the outcome of these diseases in the majority of patients. Therefore, to date, the use of NSAIDs in patients with chronic viral hepatitis does not have a further utility, and this report is of only "historical" interest. Nevertheless, the trials that have evaluated the effects of NSAIDs preceded the use of PEG-IFN and were performed with standard IFN- $\alpha$. To date, only one trial of HCV patients treated with PEG-INF and NSAIDs (ketoprofen) has been published with interesting results. Therefore, the possible usefulness of ketoprofen in combination with PEG-IFN and ribavirin for $\mathrm{HCV}$-infected patients, with particular regard to subjects who were non-responders to standard treatment or with genotype 1 , should be evaluated in future clinical trials. 


\section{Conflict of interest statement}

The authors have no conflict of interest to declare.

\section{References}

[1] Lok AS, MCMahon BJ. Chronic hepatitis B. Hepatology 2007;45(2):507-39.

[2] Lauer GM, Walker BD. Hepatitis C virus infection. N Engl J Med 2001;345(1):41-52.

[3] Fattovich G, Giustina G, Schalm SW, Hadziyannis S, SanchezTapias J, Almasio P, et al. Occurrence of hepatocellular carcinoma and decompensation in western European patients with cirrhosis type B. The EUROHEP Study Group on Hepatitis B Virus and Cirrhosis. Hepatology 1995;21:77-82.

[4] Di Marco V, Lo lacono O, Camma C, Vaccaro A, Giunta M, Martorana G, et al. The long-term course of chronic hepatitis B. Hepatology 1999;30:257-64.

[5] Baumert TF, Thimme R, von Weizsacker F. Pathogenesis of hepatitis B virus infection. World J Gastroenterol 2007;13: 82-90.

[6] [No authors listed] G lobal surveillance and control of hepatitis C. Report of a WHO Consultation organized in collaboration with the Viral Hepatitis Prevention Board, Antwerp, Belgium.J Viral Hepat. 1999;6(1):35-47.

[7] Tong MJ, el-Farra NS, Reikes AR, Co RL. Clinical outcomes after transfusion-associated hepatitis C. N Engl J Med 1995;332(22): 1463-6.

[8] Poynard T, Bedossa P, Chevallier M, Mathurin P, Lemonnier C, Trepo $C$, et al. A comparison of three interferon alfa- $2 b$ regimens for the long-term treatment of chronic non-A, non-B hepatitis. Multicenter Study Group. N Engl J Med 1995;332(22):1457-62.

[9] Di Bisceglie AM, Martin P, Kassianides C, Lisker-Melman M, Murray L, Waggoner $\mathrm{J}$, et al. Recombinant interferon alfa therapy for chronic hepatitis C. A randomized, double-blind, placebo-controlled trial. N Engl J Med 1989;321(22):1506-10.

[10] Shiffman ML, Ghany MG, Morgan TR, Wright EC, Everson GT, Lindsay $\mathrm{KL}$, et al. Impact of reducing peginterferon alfa-2a and ribavirin dose during retreatment in patients with chronic hepatitis C. Gastroenterology 2007;132(1):103-12.

[11] Shiffman ML, Di Bisceglie AM, Lindsay KL, Morishima C, Wright EC, Everson GT, et al., Hepatitis C Antiviral Long-Term Treatment Against Cirrhosis Trial Group. Peginterferon alfa-2a and ribavirin in patients with chronic hepatitis $C$ who have failed prior treatment. Gastroenterology 2004;126(4):1015-23.

[12] Lange CM, Sarrazin C, Zeuzem S. Review article: specifically targeted anti-viral therapy for hepatitis $\mathrm{C}$ - a new era in therapy. Aliment Pharmacol Ther 2010;32(1):14-28.

[13] Milazzo L, Antinori S. STAT-C: a full revolution or just a step forward? Lancet 2010;376(9742):662-3.

[14] Gaudieri S, Rauch A, Pfafferott K, Barnes E, Cheng W, McCaughan G, et al. Hepatitis C virus drug resistance and immune-driven adaptations: relevance to new antiviral therapy. Hepatology 2009;49(4):1069-82.

[15] Giambartolomei S, Artini M, Almerighi C, Moavero SM, Levrero $M$, Balsano $C$. Nonsteroidal anti-inflammatory drug metabolism potentiates interferon alfa signaling by increasing STAT1 phosphorylation. Hepatology 1999;30(2):510-6.

[16] Bahrami H, Daryani NE, Haghpanah B, Moayyeri A, Moghadam $\mathrm{KF}$, Mirmomen S, et al. Effects of indomethacin on viral replication markers in asymptomatic carriers of hepatitis B: a randomized, placebo-controlled trial. Am J Gastroenterol 2005;100(4):856-61.

[17] Andreone P, Gramenzi A, Loggi E, Favarelli L, Cursaro C, Margotti $M$, et al. In vitro effect of indomethacin and interferon-alpha on
Th1 and Th2 cytokine synthesis in patients with chronic hepatitis C. Cytokine 2004;26(3):95-101.

[18] Andreone P, Gramenzi A, Cursaro C, Biselli M, Lorenzini S, Loggi $E$, et al. Interferon-alpha combined with ketoprofen as treatment of naïve patients with chronic hepatitis C: a randomized controlled trial. J Viral Hepat 2003;10(4):306-9.

[19] Andreone P, Cursaro C, Gramenzi A, Fiorino S, Di Giammarino L, Miniero R, et al. Interferon alpha plus ketoprofen or interferon alpha plus ribavirin in chronic hepatitis $C$ non-responder to interferon alpha alone: results of a pilot study. Ital J Gastroenterol Hepatol 1999;31(8):688-94.

[20] Andreone P, Cursaro C, Gramenzi A, Buzzi A, Miniero R, Sprovieri $G$, et al. Indomethacin enhances serum 2'5'-oligoadenylate synthetase in patients with hepatitis $B$ and $C$ virus chronic active hepatitis. J Hepatol 1994;21(6):984-8.

[21] Andreone P, Cursaro C, Gasbarrini G. Interferon alpha increases prostaglandin E2 production by cultured liver biopsy in patients with chronic viral hepatitis: can non-steroidal anti-inflammatory drugs improve the therapeutic response to interferon? J Hepatol 1993;19(2):228-31.

[22] Weber F, Kochs G, Haller O. Inverse interference: how viruses fight the interferon system. Viral Immunol 2004;17(4):498-515.

[23] Haller 0 , Kochs $G$, Weber F. The interferon response circuit: induction and suppression by pathogenic viruses. Virology 2006;344(1):119-30.

[24] Vercammen E, Staal J, Beyaert R. Sensing of viral infection and activation of innate immunity by toll-like receptor 3 . Clin Microbiol Rev 2008;21(1):13-25.

[25] Halwani R, Doroudchi M, Yassine-Diab B, Janbazian L, Shi Y, Said $E A$, et al. Generation and maintenance of human memory cells during viral infection. Springer Semin Immunopathol 2006;28(3):197-208.

[26] Stockinger B, Bourgeois C, Kassiotis G. CD4+ memory T cells: functional differentiation and homeostasis. Immunol Rev 2006;211:39-48.

[27] Smith PL, Lombardi G, Foster GR. Type I interferons and the innate immune response-more than just antiviral cytokines. Mol Immunol 2005;42(8):869-77.

[28] Alcami A, Koszinowski UH. Viral mechanisms of immune evasion. Mol Med Today 2000;6(9):365-72.

[29] Blackburn SD, Wherry EJ. IL-10, T cell exhaustion and viral persistence. Trends Microbiol 2007;15(4):143-6.

[30] Loo YM, Gale Jr M. Viral regulation and evasion of the host response. Curr Top Microbiol Immunol 2007;316:295-313.

[31] Sharma-Walia N, Raghu H, Sadagopan S, Sivakumar R, Veettil MV, Naranatt PP, et al. Cyclooxygenase 2 induced by Kaposi's sarcoma-associated herpesvirus early during in vitro infection of target cells plays a role in the maintenance of latent viral gene expression. J Virol 2006;80(13):6534-52.

[32] Zhu H, Cong JP, Yu D, Bresnahan WA, Shenk TE. Inhibition of cyclooxygenase 2 blocks human cytomegalovirus replication. Proc Natl Acad Sci U S A 2002;99(6):3932-7.

[33] Gosselin J, Borgeat P. Epstein-Barr virus modulates 5-lipoxygenase product synthesis in human peripheral blood mononuclear cells. Blood 1997;89(6):2122-30.

[34] Vaddadi KS, Das UN. HIV virus, prostaglandins and essential fatty acids; a suggested mechanism for T helper cell penetration. Med Hypotheses 1988;26(4):229-30.

[35] Rehermann B, Nascimbeni M. Immunology of hepatitis B virus and hepatitis C virus infection. Nat Rev Immunol 2005;5(3): 215-29.

[36] Waris G, Siddiqui A. Regulatory mechanisms of viral hepatitis B and C. J Biosci 2003;28(3):311-21.

[37] Ray N, Bisher ME, Enquist LW. Cyclooxygenase-1 and -2 are required for production of infectious pseudorabies virus. J Virol 2004;78(23):12964-7.

[38] Davy C, Doorbar J. G2/M cell cycle arrest in the life cycle of viruses. Virology 2007;368(2):219-26. 
[39] Alcami A, Koszinowski UH. Viral mechanisms of immune evasion. Trends Microbiol 2000;8(9):410-8.

[40] Murakami M, Kudo I. Prostaglandin E synthase: a novel drug target for inflammation and cancer. Curr Pharm Des 2006;12(8): 943-54.

[41] Bos CL, Richel DJ, Ritsema T, Peppelenbosch MP, Versteeg HH. Prostanoids and prostanoid receptors in signal transduction. Int J Biochem Cell Biol 2004;36(7):1187-205.

[42] Le Page C, Génin P, Baines MG, Hiscott J. Interferon activation and innate immunity. Rev Immunogenet 2000;2(3):374-86.

[43] Siegal FP, Kadowaki N, Shodell M, Fitzgerald-Bocarsly PA, Shah $\mathrm{K}$, Ho S, et al. The nature of the principal type 1 interferonproducing cells in human blood. Science 1999;284(5421): 1835-7.

[44] Randall RE, Goodbourn S. Interferons and viruses: an interplay between induction, signalling, antiviral responses and virus countermeasures. J Gen Virol 2008;89(Pt 1):1-47.

[45] Xu D, Qu CK. Protein tyrosine phosphatases in the JAK/STAT pathway. Front Biosci 2008;13:4925-32.

[46] Murray PJ. The JAK-STAT signaling pathway: input and output integration. J Immunol 2007;178(5):2623-9.

[47] Flati V, Haque SJ, Williams BR. Interferon-alpha-induced phosphorylation and activation of cytosolic phospholipase A2 is required for the formation of interferon-stimulated gene factor three. EMBO J 1996;15(7):1566-71.

[48] Hannigan GE, Williams BR. Signal transduction by interferonalpha through arachidonic acid metabolism. Science 1991;251(4990):204-7.

[49] Hii CS, Ferrante A, Edwards YS, Huang ZH, Hartfield PJ, Rathjen $\mathrm{DA}$, et al. Activation of mitogen-activated protein kinase by arachidonic acid in rat liver epithelial WB cells by a protein kinase C-dependent mechanism. J Biol Chem 1995;270(9): 4201-4.

[50] Wen Z, Zhong Z, Darnell Jr JE. Maximal activation of transcription by Stat 1 and Stat 3 requires both tyrosine and serine phosphorylation. Cell 1995;82(2):241-50.

[51] Williams CS, Mann M, DuBois RN. The role of cyclooxygenases in 'inflammation, cancer, and development. Oncogene 1999;18(55):7908-16.

[52] Dubois RN, Abramson SB, Crofford L, Gupta RA, Simon LS, Van De Putte LB, et al. Cyclooxygenase in biology and disease. FASEB J 1998;12(12):1063-73.

[53] Waris G, Siddiqui A. Hepatitis C virus stimulates the expression of cyclooxygenase-2 via oxidative stress: role of prostaglandin E2 in RNA replication. J Virol 2005;79(15):9725-34.

[54] Koike K. Hepatitis C virus contributes to hepatocarcinogenesis by modulating metabolic and intracellular signaling pathways. J Gastroenterol Hepatol 2007;22(Suppl 1):S108-11.

[55] Waris G, Livolsi A, Imbert V, Peyron JF, Siddiqui A. Hepatitis C virus NS5A and subgenomic replicon activate NF-kappaB via tyrosine phosphorylation of IkappaBalpha and its degradation by calpain protease. J Biol Chem 2003;278(42):40778-87.

[56] Smith WL, Garavito RM, DeWitt DL. Prostaglandin endoperoxide $\mathrm{H}$ synthases (cyclooxygenases)-1 and -2 . J Biol Chem 1996;271(52):33157-60.

[57] Cheng AS, Chan HL, Leung WK, To KF, Go MY, Chan JY, et al. Expression of $\mathrm{HBx}$ and $\mathrm{COX}-2$ in chronic hepatitis $\mathrm{B}$, cirrhosis and hepatocellular carcinoma: implication of $\mathrm{HBx}$ in upregulation of COX-2. Mod Pathol 2004;17(10):1169-79.

[58] Cheng AS, Chan HL, Leung NW, Liew CT, To KF, Lai PB, et al. Expression of cyclooxygenase-2 in chronic hepatitis $B$ and the effects of anti-viral therapy. Aliment Pharmacol Ther 2002;16(2):251-60.

[59] Pereira CF, Boven LA, Middel J, Verhoef J, Nottet HS. Induction of cyclooxygenase-2 expression during HIV-1-infected monocyte-derived macrophage and human brain microvascular endothelial cell interactions. J Leukoc Biol 2000;68(3): 423-8.
[60] Janelle ME, Gravel A, Gosselin J, Tremblay MJ, Flamand L. Activation of monocyte cyclooxygenase-2 gene expression by human herpesvirus 6 . Role for cyclic AMP-responsive element-binding protein and activator protein-1. J Biol Chem 2002;277(34):30665-74.

[61] Murono S, Inoue H, Tanabe T, Joab I, Yoshizaki T, Furukawa M, et al. Induction of cyclooxygenase- 2 by Epstein-Barr virus latent membrane protein 1 is involved in vascular endothelial growth factor production in nasopharyngeal carcinoma cells. Proc Natl Acad Sci U S A 2001;98(12):6905-10.

[62] Meydani SN, Han SN, Wu D. Vitamin E and immune response in the aged: molecular mechanisms and clinical implications. Immunol Rev 2005;205:269-84.

[63] Barrios-Rodiles M, Chadee K. Novel regulation of cyclooxygenase-2 expression and prostaglandin E2 production by IFNgamma in human macrophages. J Immunol 1998;161(5): 2441-8.

[64] Mahic M, Yaqub S, Johansson CC, Taskén K, Aandahl EM. FOXP3+CD4+CD25+ adaptive regulatory $T$ cells express cyclooxygenase- 2 and suppress effector T cells by a prostaglandin E2dependent mechanism. J Immunol 2006;177(1):246-54.

[65] Katamura K, Shintaku N, Yamauchi Y, Fukui T, Ohshima Y, Mayumi M, et al. Prostaglandin E2 at priming of naive CD4+ $T$ cells inhibits acquisition of ability to produce IFN-gamma and IL2, but not IL-4 and IL-5. J Immunol 1995;155(10):4604-12.

[66] Reiss CS, Komatsu T. Does nitric oxide play a critical role in viral infections? J Virol 1998;72(6):4547-51.

[67] Fuji A, Kakumu S, Ohtani Y, Murase K, Hirofuji H, Tahara H. Interferon-gamma production by peripheral blood mononuclear cells of patients with chronic liver disease. Hepatology 1987;7(3):577-81.

[68] Flowers M, Sherker A, Sinclair SB, Greig PD, Cameron R, Phillips $M J$, et al. Prostaglandin $E$ in the treatment of recurrent hepatitis $B$ infection after orthotopic liver transplantation. Transplantation 1994;58(2):183-92.

[69] Tsuboi I, Tanaka H, Nakao M, Shichijo S, Itoh K. Nonsteroidal anti-inflammatory drugs differentially regulate cytokine production in human lymphocytes: up-regulation of TNF, IFNgamma and IL-2, in contrast to down-regulation of IL-6 production. Cytokine 1995;7(4):372-9.

[70] Kantor TG. Ketoprofen: a review of its pharmacologic and clinical properties. Pharmacotherapy 1986;6(3):93-103.

[71] Jamali F, Brocks DR. Clinical pharmacokinetics of ketoprofen and its enantiomers. Clin Pharmacokinet 1990;19(3):197-217.

[72] Caldwell JR. Comparison of the efficacy, safety, and pharmacokinetic profiles of extended-release ketoprofen and piroxicam in patients with rheumatoid arthritis. Clin Ther $1994 ; 16(2): 222-35$.

[73] Tanabe T, Tohnai N. Cyclooxygenase isozymes and their gene structures and expression. Prostaglandins Other Lipid Mediat 2002;68-69:95-114.

[74] Andreone P, Gramenzi A, Cursaro C, Bernardi M. Inhibition of the cyclooxygenase/lipoxygenase pathways to improve interferon alpha efficacy in chronic hepatitis C: don't lose the tract! Dig Liver Dis 2000;32(6):542-3.

[75] Andreone P, Cursaro C, Gramenzi A, Miniero R, Bernardi M, Gasbarrini G. Interferon-alpha plus indomethacin combined therapy in $\mathrm{HBeAg}$ positive chronic hepatitis B non-responder to a previous IFN-alpha course: results of a pilot study. International Hepatology Communications July 1996;5(3):151-9.

[76] Trujillo-Murillo K, Rincón-Sánchez AR, Martínez-Rodríguez H, Bosques-Padilla F, Ramos-Jiménez J, Barrera-Saldaña HA, et al. Acetylsalicylic acid inhibits hepatitis $C$ virus RNA and protein expression through cyclooxygenase 2 signaling pathways. Hepatology 2008;47(5):1462-72.

[77] Kapicioğlu S, Sari M, Kaynar K, Baki A, Ozoran Y. The effect of indomethacin on hepatitis $B$ virus replication in chronic healthy carriers. Scand J Gastroenterol 2000;35(9):957-9. 
[78] Anderson FH, Zeng L, Yoshida EM, Rock NR. Failure of ketoprofen and interferon combination therapy to improve interferon-resistant chronic hepatitis C. Can J Gastroenterol 1997;11(4): 294-7.

[79] Zarski JP, Maynard-Muet M, Chousterman S, Baud M, Barnoud R, Abergel $\mathrm{A}$, et al. Tenoxicam, a non-steroid anti-inflammatory drug, is unable to increase the response rate in patients with chronic hepatitis $C$ treated by alpha interferon. Hepatology 1998;27(3):862-7.

[80] Fabris P, Tositti G, Negro F, Marranconi F, Infantolino D, Rassu M, et al. Interferon alfa-2b alone or in combination with ketoprofen as treatment for interferon-naive chronic hepatitis $C$ patients. Aliment Pharmacol Ther 1999;13(10):1329-34.

[81] Muñoz AE, Levi D, Podestá A, Gorín JM, González J, Bartellini $M A$, et al. Interferon-alpha $2 b$ combined with daily ketoprofen administration improves virological response in chronic hepatitis C: a prospective and randomised trial. Gut 2000;46(3):427-31.

[82] Gramenzi A, Cursaro C, Margotti M, Balsano C, Spaziani A Anticoli $\mathrm{S}$, et al. Ketoprofen, peginterferon $2 \mathrm{a}$ and ribavirin for genotype 1 chronic hepatitis C: a phase II study. World J Gastroenterol 2009;15(47):5946-52. 